\title{
The Importance of Ion Homeostasis and Nutrient Status in Seed Development and Germination
}

 \\ Jesús Ochoa ${ }^{1}$, María José Vicente ${ }^{1,2}$, Jose A. Franco ${ }^{1,2}$, Sebastián Bañon ${ }^{1}{ }^{\circledR}$, Juan J. Martínez ${ }^{1}$ \\ and Juan A. Fernández ${ }^{1,2}$ (D) \\ 1 Departament of Agronomic Engineering, Universidad Politécnica de Cartagena, Paseo Alfonso XIII 48. \\ E-30203-Cartagena, Spain; catalina.egea@upct.es (C.E.-G.); encarnacion.conesa@upct.es (E.C.); \\ jesus.ochoa@upct.es (J.O.); maria.vicente@upct.es (M.J.V.); josea.franco@upct.es (J.A.F.); \\ sebastian.arias@upct.es (S.B.); juan.martinez@upct.es (J.J.M.); juan.fernandez@upct.es (J.A.F.) \\ 2 Instituto de Biotecnología Vegetal, Campus Muralla del Mar, 30202- Cartagena, Spain \\ * Correspondence: mcarmen.ballesta@upct.es
}

Received: 26 February 2020; Accepted: 30 March 2020; Published: 2 April 2020

Abstract: Seed is the dissemination unit of plants initiating an important stage in the life cycle of plants. Seed development, comprising two phases: embryogenesis and seed maturation, may define the quality of sown seed, especially under abiotic stress. In this review we have focused on the recent advances in the molecular mechanisms underlying these complex processes and how they are controlled by distinct environmental factors regulating ion homeostasis into the seed tissues. The role of transporters affecting seed embryogenesis and first stages of germination as imbibition and subsequent radicle protrusion and extension were revised from a molecular point of view. Seed formation depends on the loading of nutrients from the maternal seed coat to the filial endosperm, a process of which the efflux is not clear and where different ions and transporters are involved. The clear interrelation between soil nutrients, presence of heavy metals and the ion capacity of penetration through the seed are discussed in terms of ion effect during different germination stages. Results concerning seed priming techniques used in the improvement of seed vigor and radicle emergence are shown, where the use of nutrients as a novel way of osmopriming to alleviate abiotic stress effects and improve seedlings yield is discussed. Novel approaches to know the re-translocation from source leaves to developing seeds are considered, as an essential mechanism to understand the biofortification process of certain grains in order to cope with nutrient deficiencies, especially in arid and semiarid areas. Finally, the role of new genes involved in hormone-dependent processes, oxidative response and water uptake into the seeds during their development or germination, have been described as plant mechanisms to deal with abiotic stresses.

Keywords: abiotic stress; biofortification; embryogenesis; germination; heavy metals; priming; seed development

\section{Introduction}

Seed is the unit for plant reproduction and the first stage of plant development. It is composed of three elements; embryo, endosperm and seed coat. The embryo will generate the complete plant, the endosperm accumulates all the nutrients that the embryo needs during its development and the seed coat constitutes the protection structure.

Seed formation starts with a double fertilization, followed by the dormancy and germination of the seed. Different cellular divisions and differentiations of the formed zygote after fertilization occurred during plant embryogenesis. In a second phase, the maturation of the seeds involves cell 
growth and the storage of macromolecules, with coat filling and nutrient tissue distribution during seed formation. The ion homeostasis between different seed compartments, that is regulated during these processes, is still a matter of debate.

Seed mineral reserves and their translocation may determine further plant vigor and performance, and abiotic stress conditions may disturb this ion balance [1]. However, although many studies have been focused on the composition of the storage material in the embryo and endosperm [2], there is a lack of information about the distribution of macro and micro elements in the seed coat, how they can affect seed development and germination and the molecular mechanisms that control ion translocation in order to ensure the next plant generation, especially under stress conditions.

From a plant nutritional point of view, important macronutrients such as nitrogen result in changes of the endosperm structure, influencing seed moisture and therefore subsequent germination stages [3]. Also, calcium may act as a molecule signal at tonoplast level, determining the vacuole filling, seed size and embryogenesis, among other processes [4]. Different technologies such as X-ray photoemission spectroscopy (XPS) or scanning electron microscopy (SEMEDX) have been used to determine ion distribution in the seed coat, highlighting new mechanisms involved in the response of the seed to osmotic agents (osmopriming), where a redistribution between the outer and inner coat layers may favor water uptake and promote the diffusion of beneficial substances for germination [5].

Also, the content of different ions could be related to the biosynthesis and metabolism of certain hormones and vice versa, connecting nutrient and hormone signaling pathways during seed development and germination. In fact, some hormones such as ABA and Gibberellin (GA) play an important role during the stages of germination, especially under abiotic stresses, such as extreme temperatures, salinity or drought [6-8]. In these reports, hormones are regulated by distinct transcription factors showing the complexity of seed germination regulation and the network of genes involved in the stress response to ensure water uptake and the radicle protrusion.

One of the main events during seed development is the starch metabolism or storage protein mobilization, where several enzymes participate. Unfavorable soil conditions may alter these events. Thus, the presence of different heavy metals as well as different salts such as $\mathrm{NaCl}$ influences this seed metabolism and the enzymes. In this sense, differences in the seedling response depend on each genotype and its ability to allow ion penetration through the seed coat to cope with unfavorable environments.

Seed osmopriming has been outlined as an agricultural practice to prevent abiotic stress damage, affecting different mechanisms in which changes in inorganic and organic solute concentrations in the organs of the plant could be induced. Furthermore, modification of nutrient use efficiency by seedlings could be the result of seed priming, where transporters such as vacuolar $\mathrm{Na}^{+} / \mathrm{H}^{+}$antiporter (NHX), potassium transporter (HAK) and chloride channel protein (CLC) are required [9]. However, studies of seed osmopriming as an efficient mechanism to face stress in the field are not conclusive. What it is clear is that the mechanisms involved during seed development, maturation and subsequent germination may determine the factors that condition the good quality of the seed, increasing the yield of the plant and food security. Among these mechanisms, processes related to ion homeostasis have been less studied, in spite of their importance, due to difficulties in determining ion distribution and the spatial-temporal location of distinct macro and micro nutrients in the seeds.

Transcriptomic studies and novel genomic tools such as CRISPR/Cas9 edition have been applied to integrate seed size and abiotic stress tolerance traits through the previous identification of the genes and transcription factors involved in these two plant traits [10]. The last technique produces genome-edited plants with no transgenic characteristics and it has been considered as a promising tool in future commercial applications and plant breeding programs.

\section{Ion Homeostasis during Seed Formation: From Maternal Phloem to Seed Coat}

Seed formation depends on the loading of nutrients from the maternal phloem of the seed coat to the filial cotyledon (endosperm and embryo) of developing seeds (Figure 1). The efflux transfer 
cells located in the maternal tissues are responsible for the release of nutrients into the filial apoplasm. In these cells, membrane transporters, aquaporins, and channels for sugars, amino acids and peptides or inorganic ions have been found at the plasma membrane playing a key role [11,12].

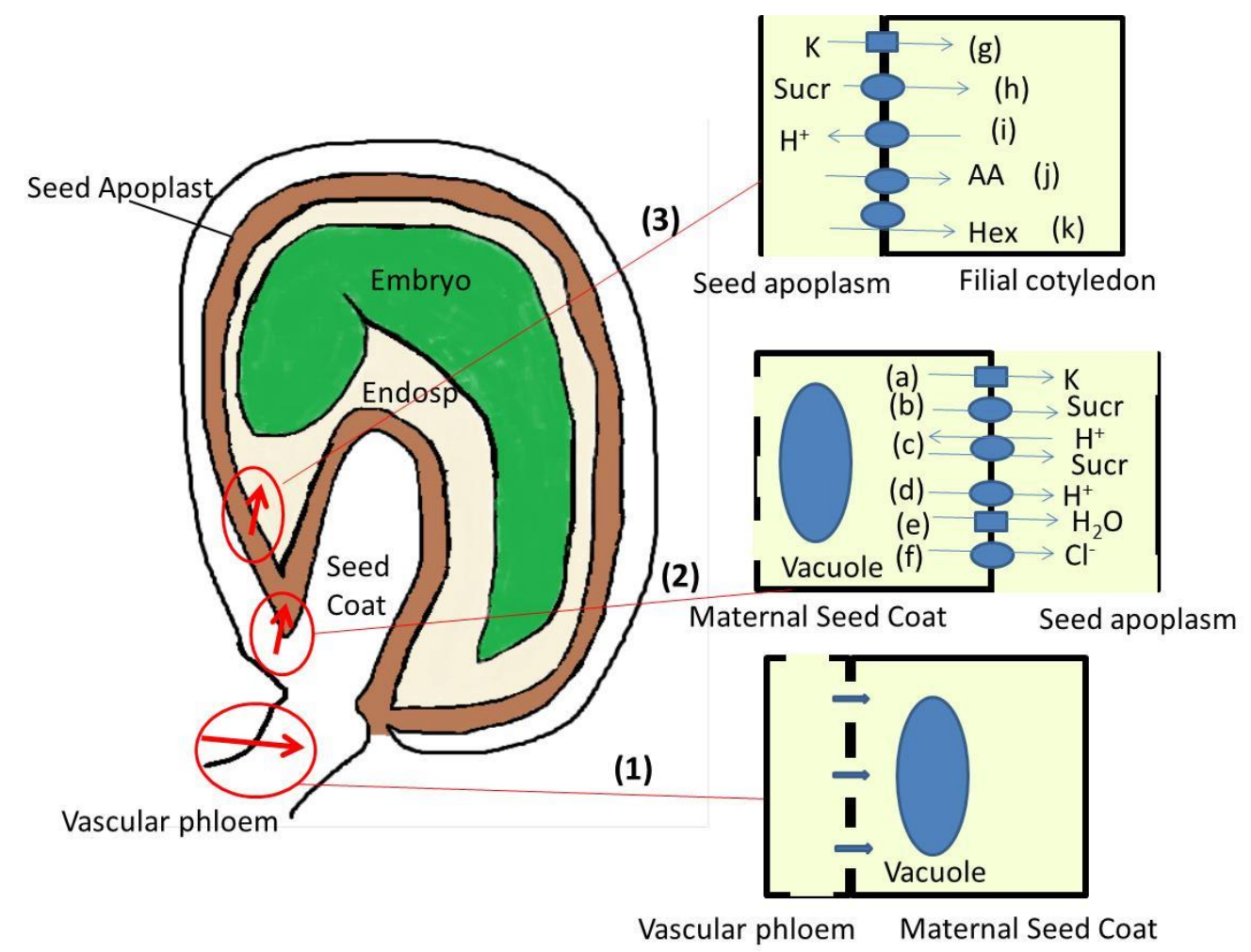

Figure 1. (1) Cellular efflux of phloem-imported nutrients to the maternal seed coat occurred through the plasmodesmata. (2) Nutrient transport from the maternal seed coat to the seed apoplasm involves different transporters situated in the plasma membrane as a) non-selective channel; (b, c) sucrose/H+ carriers and symporters; (d) H+-ATPase; (e) aquaporins; (f) $\mathrm{Cl}^{-}$channel and finally (3) Nutrient transport from the seed apoplast to the plasma membrane of cotyledons (embryo and endosperme tissues) involves transporter as (g) non-selective cation channel; (h) sucrose transporters (i) $\mathrm{H}^{+}$-ATPase; (j) amino acid transporters and (k) hexose transporters.

In addition to carbon and nitrogen, in the form of sucrose and amino acids, respectively, other macro and micro elements such as inorganic phosphate $(\mathrm{P})$, potassium $(\mathrm{K})$, zinc $(\mathrm{Zn})$ sulfur $(\mathrm{S})$ and iron $(\mathrm{Fe})$ are transferred into the filial seed with important functions in seed development and production.

$\mathrm{P}$ is one of the most acquired nutrients by seeds and it has been reported that its elevated content may favor seed vigor and an initial seedling establishment $[13,14]$. In the seed, $\mathrm{P}$ is stored mainly as phytic acid (myo-inositol-1,2,3,4,5,6-hexakisphosphate, InsP6), which is a strong chelator of micronutrients such as $\mathrm{Zn}$ and Fe, affecting the content of microelements in different grains. Thus, from a human nutritional point of view, some important micronutrients deficiencies in cereals have been related to a high content of phytates in the seeds [15].

Plasma membrane $\mathrm{P} / \mathrm{H}^{+}$co-transporters of the PHT1 family were found in the seed tissues of rice (Oryza sativa) and wheat (Triticum aestivum) [16-18]. Although their role in P xylem loading from roots is clear, their participation in Pi transference from the maternal to filial seed tissues has not been elucidated. This is due to the fact that maternal and filial tissues are symplastically isolated and it is poorly described if movement of some nutrients occurs through an apoplastic route, or by the combination of the above route with a symplastic pathway, where transporters are positioned in series in both maternal seed coat and filial cotyledon membranes [19]. 
Recently, it has been proposed that the root P exporter, PHO1, was a key element of Pi flux between the seed coat and embryo in Arabidopsis seeds. This transporter was found expressed in the chalazal seed coat (CZSC) of developing seeds, and mutants of pho1 retained a 2-fold higher content of $\mathrm{P}$ than the wild type control, at the mature green stage of the seed development [20].

Also, $\mathrm{K}$ is a predominant cation released from the phloem of the coats to the seed apoplasm during seed development. Its delivery occurs through interconnecting plasmodesmata and it is included in labile storage vacuoles together other nutrients, during the subsequent symplasmic translocation. The recovering of the leaked nutrients to the apoplasm, especially $\mathrm{K}$, during symplasmic transport is mediated by several membrane transporters, such as the nonselective cation channel and $\mathrm{Cl}^{-}$ channels $[19,21]$

Transition metals such as $\mathrm{Fe}, \mathrm{Zn}$ and $\mathrm{Cu}$ also play an important role in seed development. It has been reported by a proteomic study that some of the main proteins participating in seed growth include Fe- (lipoxygenase, succinate dehydrogenase, ferritin, APX, and peroxidase), $\mathrm{Cu}$ - ( $\mathrm{Cu}$ chaperone), and $\mathrm{Zn}$-requiring (alcohol dehydrogenase and zinc metallopeptidase) proteins [22]. However, some of the transition metals such as Fe present problems of mobility into the phloem due to the ion precipitation at the characteristic alkaline $\mathrm{pH}$ of the phloem sap. To ensure Fe translocation from the maternal phloem to filial seeds, the chelator Nicotianamine (NA) is a determinant [23], where the membrane transporters belonging to the YSL family are responsible for the transport of the NA-Fe complex. Thus, single [24] and double [25] knockout Arabidopsis mutants for ysl transporters presented a decreased transition metal, which resulted finally in small seeds. In addition, another of the identified Fe-transporters in the phloem was a $11 \mathrm{kDa}$ Fe transport protein (ITP), participating in Fe transitions into the seeds [26].

Sulfur (S) is other important ion during seed development and it has been shown that it is delivered into the seeds across the phloem as sulfate ion in grain legumes [27]. Sulfate recovery by sulfate transporters in the phloem contributes to seed development [28]. Under sulfur deficiency, seeds of Medicago truncatula germinated slowly and their vigor were decreased compared with S-supplied seeds. Although these S-deprived seeds were able to sustain carbon and nitrogen remobilization through a continuous sulfate efflux from the vacuole, their germination was delayed [29]. The authors proposed that an active metabolism for allocation of different resources into the seeds was maintained by the leaf vacuolar sulfate transporter, MtSULTR4;1. Thus, reduced levels of sulfur were reflected in decreased levels of sucrose and proteins that finally affected seed germination and development [29].

In addition, sulfur is involved in the formation of sulfur complexes or sulfur proteins with $\mathrm{Fe}$, allowing Fe remobilization at the maternal-filial interface endosperm as another way of $\mathrm{Fe}$ complexation [30].

Calcium is a well-recognized signaling element of many processes in plants. However, its participation in seed development processes has not been widely studied. Proteomic studies have reported several $\mathrm{Ca}^{2+}$-binding proteins and kinases in the phosphoinositide/ $/ \mathrm{Ca}^{2+}$ signaling pathway during seed formation and development [31]. Thus, $\mathrm{Ca}^{+2}$ may participate in the turgor homeostat mechanism at seed maternal tissue level, increasing $\mathrm{Ca}^{+2}$ cytosolic levels which act as signals to activate $\mathrm{Cl}^{-}$and sucrose transporters [19]. A signaling network involving calcineurin B-like (CBL) protein calcium sensors has been also described at plasma membrane and tonoplast levels in Arabidopsis plants [4]. Mutants for these $c b l$ genes in the tonoplast showed seeds with smaller size and a decreased weight and fatty acid content compared to wild-type seeds [4]. It was found that phosphatidylinositol-6 phosphate (InsP6), an abundant form of Pi in seeds, was reduced in one of the mutants as well as the levels of $\mathrm{K}$ and magnesium $(\mathrm{Mg})$ that usually are complexed with InsP6 in the embryo $[4,32,33]$. These results indicated a $\mathrm{Ca}^{2+}$ dependent regulation of InsP6 content and therefore, $\mathrm{K}$ and $\mathrm{Mg}$ levels complexed by InsP6, through a controlled deposition of InsP6 in the vacuole during seed embryogenesis.

In addition to the plasma membrane transporters, a recent role that has been attributed to tonoplast transporters is the control of the ion acquisition in the embryo. It was observed that two vacuole transporters VIT1 and MTP8 were responsible for the cell layer accumulation of Fe and Mn in 
Arabidopsis seeds $[34,35]$. Thus, VIT1 is expressed early in the torpedo stage and MTP 8 is expressed later during the bent-cotyledon stage. These tonoplast transporters may regulate the timing of translocation and accumulation of metals from the endosperm to the embryo, probably through the control of the embryo metal status on plasma membrane transporters expression [36].

Therefore, not only the seed mineral content, but also the knowledge about the distribution of ions in the seed and their selective accumulation in different tissues may establish the basis of the movement and barriers during nutrient translocation that affect the growth of the seedling. However, the information about ion distribution in the seed tissues is limited and more studies are necessary. Therefore, through the use of energy dispersive $\mathrm{x}$-ray (EDX) analysis, atomic absorption spectrometry (AAS) or PIXE methodology [37], locations of distinct ions in the seed tissues have been described, showing differential patterns. Thus, it is known that $\mathrm{P}, \mathrm{K}$, and $\mathrm{Mg}$ were present at higher proportion in the embryonic region of barley plants than in the cotyledons and seed coat, while no specific $\mathrm{Ca}$ distribution pattern was found. A high content of $\mathrm{Zn}, \mathrm{Cu}$, and $\mathrm{Mn}$ was also found inside the embryonic region, and the correlation of these elements with $\mathrm{P}$ suggest their association as phytates. It is well known that mainly $\mathrm{P}$ as well as other cations $(\mathrm{K}, \mathrm{Mg}, \mathrm{Ca}, \mathrm{Mn}, \mathrm{Fe}$ and $\mathrm{Zn})$ are accumulated in seeds as phytates and they are released during germination by the activity of phosphatases and phytases in dry seeds [38]. Similar results to barley grain where found for $\mathrm{Zn}, \mathrm{Mn}$ and Fe distribution in the seeds of Arabidopsis plants [39]. Fe localization within the seed was modified by the disruption of the vacuolar Fe transporter VIT1Fe [40], showing that ion redistribution is also a process dependent on transporter activity.

Positive (Fe and $\mathrm{Zn}$ ) or negative ( $\mathrm{Ca}$ ) correlations of the elements with seed coat lightness and seed vigor were established. Other elements were positively ( $\mathrm{K}, \mathrm{P}, \mathrm{Mg}$ and $\mathrm{Mn}$ ) or negatively (Fe) correlated with primary shoot length, shoot dry mass and root dry mass in seedlings after germination [37]. Also, in legumes such as Lotus japonicus, ion correlations with seed vigor were also found, and $\mathrm{Fe}, \mathrm{Cu}$, $\mathrm{Mg}, \mathrm{Mn}$, and $\mathrm{Zn}$ showed a similar distribution pattern in the seeds of this plant [41]. In Arabidopsis, $\mathrm{Fe}$, $\mathrm{Zn}$, and Mn were localized in different regions in the mature seed cotyledon and radicle [42] and a genotype dependence of ion distribution was also shown in the seeds of common beans [43], pointing to the correlation between the ion distribution in the seeds and their development.

As seeds are the final target for nutrients in the life cycle of plants, in addition to transporter gene identification, understanding their function and distribution may increase our knowledge about seed homeostasis. The main gap, as well as the recent advances reflected in this review, indicate the current status of seed nutrition.

\section{Importance of Soil Nutrients in Seed Germination, Development and Seed Pools}

The importance of an adequate nutrient content in soils, conditioning seed germination, has been demonstrated in numerous reports. An imbalance of nutrients in the soil or an excess of ions may affect seedling development through an initial effect on the seed growth. On the other hand, an increased macronutrient concentration in the soil may provide seeds with elevated levels of $\mathrm{P}$ and $\mathrm{N}$ and high quality. In a nutrient study with the harmful weed, Solanum viarum, [44] seeds were stimulated under nutrient rich soil conditions and light. In the absence of $\mathrm{P}$, the percentage of germination was reduced to $66 \%$ and the lack of nitrogen $(\mathrm{N})$ completely inhibited seed germination, under constant light conditions. The results highlighted not only the relevance of the nutrient medium, but also the interrelation between different nutrients such as $\mathrm{P}$ and $\mathrm{N}$ and the interaction between nutrition and light status for the germination of these seeds. The complex relation between light and hormone signals under optimal nutrition must not be disregarded.

A genotype-dependent threshold in nutrient supply has also been described, that may control seed germination, which is relevant in order to reduce undesirable weed competition with economical value crops. Thus, it has been observed that $\mathrm{N}$ breaks the dormancy of many seeds, altering weed-infestation expansion. Therefore, an adequate $\mathrm{N}$ management may protect crop yields through a differential germination rate depending on the genotype. A similar effect was shown for $\mathrm{K}$ in the perennial 
pepperweed (Lepidium latifolium L.) plants, where the highest germination rate $(61 \%)$ was obtained at low $\mathrm{K}$ concentration ( $0.02 \mathrm{M} \mathrm{KNO}_{3}$ ); but at higher concentrations, it was significantly reduced [45].

Recently, the influence of $\mathrm{N}$ fertilization on seed germination speed was evaluated in wheat plants [3]. Low and moderate N-fertilized plants, N (0 and $180 \mathrm{~kg} / \mathrm{ha})$, showed significantly higher rates of germination of their seeds and an elevated moisture content compared to the seeds of high $\mathrm{N}$-fertilized $(240 \mathrm{~kg} / \mathrm{ha})$ plants. In the study, a model of $\mathrm{N}$-fertilization affecting endosperm seed structure through changes in the protein content was proposed. Thus, this structural endosperm modification may influence water uptake by the seed that, together with an enhanced cell wall metabolism, may promote radicle protrusion.

Also, in Peucedanum oreoselinum (L.) Moench plants it has been found that the great phenotypical variations in the seed biomass could be related to the soil fertility, with a positive correlation between seed mass and the total germination [46]. However, in Pastinaca sativa seeds, germination was faster when they were smaller. Therefore, the relation between speed germination and soil nutrients must be further studied for each genotype and type of soil [47].

In the interrelation of soil elements, the availability of a specific ions may condition the effect of other elements on seed development. This was the case of P fertilization that affected the silicon (Si) action on seed quality [48]. The authors observed in white oat (Avena sativa L.) plants that Si had an interactive effect with $\mathrm{P}$ at elevated $\mathrm{P}$ concentrations $\left(200 \mathrm{mg} \mathrm{dm}^{-3}\right.$ of $\left.\mathrm{P}_{2} \mathrm{O}_{5}\right)$. Under low levels of $\mathrm{P}$ in the soil (20 $\mathrm{mg} \mathrm{dm}^{-3}$ of $\left.\mathrm{P}_{2} \mathrm{O}_{5}\right)$, Si had no effect on seed quality parameters, but seed dry matter was higher than when $P$ was applied at high levels. In this case, high concentrations of $P$ can reduce the quality of the seed through greater tillering of the plants and the production of weaker seeds. By contrast, other authors have reported how elevated P may increase vegetable seed production though without an improvement on seed quality [49]. In the same way, the seed yield in Capsella bursa-pastoris L. plants was affected by the nutrient supply. The number of pods and the number of seeds per pod varied according to changes in the nutrient supply [50]. The plants in the treatments with a higher availability of NPK nutrition produced 40 -fold more seeds than control plants that were not supplemented by NPK.

The importance of ion homeostasis and how this can be regulated by hormone signaling was also studied by Planes et al. [51] in Arabidopsis plants. A nontranscriptional mechanism of the hormone abscisic acid (ABA) on the inhibition of germination and seedling growth was described. The involvement of a plasma membrane (PM) $\mathrm{H}^{+}$-ATPase and the decrease in $\mathrm{K}^{+}$, and $\mathrm{Cl}^{-}$fluxes were observed together with the ABA action. In the proposed system, ABA activates AHA2 $\mathrm{H}^{+}$-ATPase phosphorylation. This leads to the ATPase inactivation and cytosolic acidification, which inhibits seed germination. Simultaneously, ABA promotes $\mathrm{K}^{+}$efflux though the GORK channel and $\mathrm{Cl}^{-}$ efflux through the SLAH3 channel resulting in a loss of turgor that also leads to the inhibition of seed germination. As ABA is a critical hormone in the response of plants to different stresses, the understanding of this effect on germinating seeds is basic in order to discern the mechanisms of stress affecting seed germination. In any case, the connection between other hormones and ion homeostasis in the seed during the different germination stages needs further investigation.

In addition to the importance of soil ions in seed germination, because plant seeds are highly sensitive to the soil environment, seed germination has been widely used to monitor toxicity in contaminated ecosystems [52]. A detailed study reported how high levels of nutrients in water and sediments from three different sources (river, thermal ponds, and control ponds) recollected in Albanis affected the germination of Sinapis alba L. seeds with toxic and/or stimulant effects [53]. No significant differences on seed germination were found among the three nutrient sources. However, in all cases, positive correlations were found between seed germination and the concentrations of $\mathrm{Cu}$ and $\mathrm{Li}$ in the sediment. Also, concentrations of sulfate, $\mathrm{Ba}, \mathrm{Mg}$ and $\mathrm{Ni}$ in the water resulted in the stimulant effect of some ions ( $\mathrm{Li}, \mathrm{Ba}$ and $\mathrm{Ni}$ ), until now considered phytotoxic for plant growth by other authors $[54,55]$.

Finally, the positive repercussion of an adequate fertilization ameliorating climatic change effects on seed filling should be considered. Thus, it has been shown in oilseed rape that the control of $S$ 
fertilization under heat stress improved grain quality and reduced the detrimental effects of climate change [56].

Germination and dormancy breakdown, as events induced in the soil conditions, widely depends on the nutrient soil status. The relation of nutrients, with antagonistic or synergistic signaling pathways induced by hormones or light, needs to be elucidated to better understand the nutrition seed response under a wide range of environmental situations.

\section{Effect of Seed Priming on Ion Homeostasis to Cope with Abiotic Stress}

Seed priming has been widely used as a technique to improve seed vigor, emergence rate and uniformity of germination under different abiotic stress conditions, especially saline and osmotic stresses, high or low temperatures and water deficit [57,58]. In addition to water hydration, osmotic solutions have been applied as soaking seed medium; its low water potential allows a slow imbibition of the seed during the initial phases of germination but without the root radicle protrusion [59]. Different inorganic salts such as $\mathrm{NaCl}, \mathrm{KCl}, \mathrm{KNO}_{3}, \mathrm{~K}_{3} \mathrm{PO}_{4}, \mathrm{KH}_{2} \mathrm{PO}_{4}, \mathrm{MgSO}_{4}$, and $\mathrm{CaCl}_{2}$ have been used in osmopriming [60-62]. In these reports, the effect of priming was tested in many crops under a wide range of environmental conditions in order to induce a suitable germination [58].

In addition to ions, other agents such as osmotically active solutes have been used in seed priming to increase abiotic stress tolerance. Plants from primed seeds may improve their growth under stress conditions due to an increased osmotic adjustment, enzyme activation, embryo enlargement and energy metabolism in the seeds that allow a fast-cellular defence response (Figure 2).



Figure 2. Effects of osmo-priming on water content and different events in the seeds during the phases of germination (adapted from [61]).

Farooq et al. [63] applied distinct priming treatments to rice seeds, including $\mathrm{KCl}, \mathrm{CaCl}_{2}$ (both at $\Psi \mathrm{s}-1.25 \mathrm{MPa})$ and ascorbate $\left(10 \mathrm{mg} \mathrm{L}^{-1}\right)$. The authors observed in all priming treatments a dormancy breakdown regarding control, but a higher rate of germination and synchronization after $\mathrm{KCl}$ seed priming. A favored and increased $\alpha$-amylase activity converted starch to reducing sugars after this seed treatment improved seed metabolism [63].

Along with the salt concentration, the nature of ions may also influence seed germination after soaking. In sunflowers (Helianthus annuus L.), an osmotic rather than a toxic effect was responsible for inhibition of germination [64]. After $\mathrm{NaCl}$ and $\mathrm{KCl}$ soaking $(-2.24 \mathrm{MPa})$, the absorption of $\mathrm{Na}^{+}$, $\mathrm{K}^{+}$, and $\mathrm{Cl}^{-}$ions into the seeds maintained a water potential gradient that avoided the induction of 
high reductions in germination, as compared with polyethylene glycol (PEG) osmopriming, even at a higher osmotic potential (-1.34 MPa) treatment.

Together with the ion transport into the seed, water uptake has been shown to play an important role in the seed size and the stimulating effect of priming. Different approaches, including nuclear magnetic resonance (NMR) spectroscopy, transmission electron microscopy (TEM), and scanning electron microscopy (SEM) were used to determine seed water status, where modifications in the expression of the plasma membrane (PIP) and tonoplast (TIP) aquaporins genes were involved [65]. Variations in the kinetics of water uptake of unprimed and PEG primed Brassica napus seeds have been described and hydration appeared faster in primed seeds compared with unprimed ones, during imbibition.

de Oliveira et al. [66] showed in sorghum seeds an increase in germination under saline stress after osmopriming, that was associated with a higher water uptake and an elevated percentage and velocity of seed germination. The authors proposed increments in the synthesis of proteins and the reparation of damage to the membranes. Also, the enhanced water content may activate enzymes responsible for embryo development and mining of the starchy endosperm.

In addition, osmopriming may change the microstructural features of the seed coat, as shown with a reduction in the number of vacuoles while its volume was enhanced [67]. It has been suggested that overlapping mechanisms induced by priming could operate in the seed hydration during later germination with the involvement of different functional proteins including aquaporins, and in particular, TIP aquaporins [67].

Thus, plasma treatment of the water for seeds irrigation has been accomplished in order to improve germination, where the mechanism of ion remobilization seems to operate. In quinoa (Chenopodium quinoa Willd. var. atlas) plasma treated seeds, a decreased amount of potassium ions and nitrate species were observed in the outer layers of the seed coats, while an increase was produced in the seed pericarps [5]. It has been proposed that the ion elimination from the seed surface and the inner accumulation may favor quinoa germination under water vapor exposure.

In other reports it has been shown that seed priming may activate the antioxidant defence system (such as superoxide dismutase, catalase, and glutathione reductase) in the plant tissues under biotic and abiotic stress $[68,69]$. Hussain et al. [70] found that selenium- or salicylic acid-priming ameliorated the negative effects of nutrient deprivation in rice plants. The authors observed that these seed priming treatments maintained the antioxidant capacity of rice seedlings and that reactive oxygen species (ROS) were significantly decreased, thereby enhancing rice growth under nitrogen-(N), phosphorus-(P), or potassium-(K) deprivation. Also, arsenic silicon priming alleviated the toxicity of arsenic on Oryza sativa L. seeds through an increase in the antioxidant capacity of the seeds, and enhanced stress modulator (cysteine and proline) levels and enzymes related to the ascorbate-glutathione cycle [71]. An improved seed quality after osmopriming was also associated with a reduction in the lipid peroxidation by the promotion of the antioxidant defence systems in the seeds [72].

Less studied is the effect of priming on other processes such as chromatin modifications, alterations of primary metabolism, and an accumulation of dormant mitogen-activated protein kinases that were also related to priming treatments [73]. Thus, the cascade of events that are activated by priming the seeds, including processes related to DNA repair, needs further investigation.

Finally, one of the main uses of priming is the alleviation of stressful abiotic conditions for plants in soils, especially salinity. One of the mechanisms of plants to cope with salt stress is the osmotic adjustment, where osmotically active solutes are accumulated in the cytoplasm [74]. Seed priming with these solutes or other ions has shown positive effects in the alleviation of salt stress symptoms in adult plants. Thus, soaking seeds in ascorbate, salicylic acid, kinetin and $\mathrm{CaCl}_{2}$ for $12 \mathrm{~h}$ resulted in a high salt stress tolerance in wheat plants, with increments in $\mathrm{K}$ accumulation and reductions in $\mathrm{Na}$ content in their leaves [75]. Also, a decreased $\mathrm{NaCl}$ toxicity was observed after priming turfgrass seeds with glycine betaine [76] or after the osmopriming with PEG-6000 in sorghum seeds, demonstrating a palliative effect even in low quality seeds [77]. 
In pea seeds, boron (B) and calcium (Ca) priming increased the number of germinated seeds under moderate salt stress $(75 \mathrm{mM} \mathrm{NaCl})$, but it did not prevent $\mathrm{NaCl}$ damage at high concentrations (150 $\mathrm{mM})$ [78]. The authors proposed that $\mathrm{B}$ and Ca remobilized seed nutrient stores and affected $\mathrm{Na}$ and $\mathrm{K}$ fluxes.

Nutrient priming with $\mathrm{KCl}$ or $\mathrm{KNO}_{3}$ improved $\mathrm{K}$ supply to plants, which helped plants to cope with salt stress. It is well known that $\mathrm{K}$ is an important osmoticum and it has a key role in maintaining turgor during radicle cells elongation. Thus, germination percentage, rate index, coefficient and seedling vigor indexes were increased after $50 \mathrm{mmol} \mathrm{L}^{-1} \mathrm{KNO}_{3}$ priming in maize plants as a consequence of a low $\mathrm{Na} / \mathrm{K}$ ratio [79]. An enhanced expression of the proline synthesis gene P5CSA was observed after this seed osmopriming, improving Brassica napus germination under salt stress. Also, molybdenum (Mo) osmopriming has been shown to play an important role in improving seed germination and the growth of common bean (Phaselous vulgaris L.) plants, through an enhanced net $\mathrm{CO}_{2}$ assimilation rate, chlorophyll content and biological nitrogen fixation [80].

In addition to Mo as a micronutrient, other microelements have demonstrated their effectivity in different crops. This is the case of boron (B) in stevia, $\mathrm{Zn}$ in maize [81] or manganese (Mn) and $\mathrm{Zn}$ in wheat [82], leading in all cases to an improved germination and development of the seedling.

Therefore, different seed osmopriming treatments have resulted in being useful for enhancing seed performance or for allowing germination under distinct stressful environments, depending on plant genotype, seed morphology and the nature of the applied ions [83]. In general, these treatments target the pregerminative metabolism of seeds, which may include not only an antioxidant response or DNA repair pathways, but also ion homeostasis and nutritional effects of the applied element.

Thus, hydropriming and osmopriming may act on hydrolytic enzymes such as endoxylanases and phytases, involved in the starch breakdown, cell wall, and phytates degradation of previous radicle protrusion. Mobilization of sugars to the growing embryo occurs and phytate hydrolysis increases phosphate, mineral elements, and myo-inositol availability. This bioavailability of elements, especially $\mathrm{Fe}$ and $\mathrm{Zn}$ that are strongly complexed by phytic acid, may lead to a better nutritional seed status in order to cope with abiotic stress. New knowledge of the relationship between ion homeostasis, seed water status and biochemical pathways involved in the seed metabolism, may help to optimize agricultural practice and design new and efficient protocols for osmopriming.

\section{Heavy Metals: Effect on Seed Germination and Development}

Soil is the natural medium and essential resource for seed germination. Amounts of metals must be taken from the soil medium and transported to the sink tissues, as seeds. However, in recent years, industrial activity and anthropogenic lifestyles have led to an elevated soil contamination, with numerous pollutants and salinity problems restricting the growth of plants.

Seed coats are the main barrier to contaminants, and prevent toxic effects of heavy metals on embryos, but it depends on the physical and chemical properties of the seed coat as well as the ability of the metal to penetrate into the seed [84]. Some seeds are covered with axy substances as cuticle and suberin, restricting metal transport, and this suberization is also developmentally regulated [84].

Some metals such as $\mathrm{Zn}, \mathrm{Cd}$ or Fe are essential ions for the plant, but at high concentrations may be toxic. These metals are able to disturb physiological processes involved in germination once they have passed through the seed coat.

In the translocation process from maternal to filial tissues and storage, the metals must cross different membranes and the transporters play a key role. Differential distribution of these transporters and regulation, as we have seen above, must be clarified to understand the effect of heavy metals on seed development. In fact, several genetic factors that regulate metal homeostasis within the embryo have been identified. Fe from chloroplasts of maturing embryos has shown to be mobilized by the YSL protein, YSL6. However, results of the involvement of this protein at embryo level show the necessity of adequate transporter localization [85]. 
Although both germination and early seedling growth stages are the most sensitive stages to metal toxicity, more so than the whole developed plant, differential effects of the heavy metals have been observed in the two plant stages [86]. Thus, Arabidopsis seedling growth was more sensitive to $\mathrm{Hg}, \mathrm{Pb}, \mathrm{Cu}$ and $\mathrm{Zn}$ compared to the germination of their seeds and only $\mathrm{Cd}$ exhibited a similar effect on both processes [86]. The results showed distinct degrees of heavy metal adaptation depending on the physiological plant stage. In addition, $\mathrm{Hg}$ was more toxic $12-24 \mathrm{~h}$ after imbibition while $\mathrm{Cd}$ toxicity was more acute at $0-12 \mathrm{~h}$ after imbibition, which was associated with the selectivity of seed coat for ion absorption at different rates and time-terms. In any case, the efficiency of the seed coat to protect the seed against the effect of heavy metals has been questioned and some controversial results have been found. Histochemical methods demonstrated the exclusion of heavy metals by seed coat in some genotypes, but by contrast, a considerable strontium ( $\mathrm{Sr}$ ) accumulation was observed in imbibing maize (Zea mays L., cv. Diamant) caryopses seeds after 24 h [87], where Sr was mainly localized in the cell wall and its rapid absorption by the seed at radicle stage was demonstrated. Another factor to consider is the interaction between different heavy metals, for example, chromium $(\mathrm{Cr})$ may interfere with the uptake and distribution of other metals such as $\mathrm{Fe}, \mathrm{Mn}, \mathrm{Ca}, \mathrm{Mg}, \mathrm{K}$, and $\mathrm{P}$ that are necessary for seed metabolism [88].

It has been shown that some heavy metals, such as $\mathrm{Cu}$ and $\mathrm{Cd}$, may modulate the osmotic strength into the cell of grains, such as rice, during germination, through the upregulation of the enzyme aldose reductase (AR) involved in osmotic homeostasis $[89,90]$. $\mathrm{Cu}$ and $\mathrm{Cd}$ also influenced the synthesis and folding of different proteins involved in germination. Thus, the activity of the protein $\beta$-glucosidase, which was in the cell wall polysaccharide metabolism and structure, was modified in an attempt to maintain an optimal modulation of the cell wall for seed radicle extrusion [31].

Mobilization of storage proteins into the seed is another process affected by heavy metal contamination. Protein remobilization was inhibited under $\mathrm{Cu}$ and $\mathrm{Cd}$ treatments in legumes, which provoked $\mathrm{N}$ deficiencies and reduced amino acid content in the embryo, limiting germination [91,92]. Similar mobilization inhibitions were observed for nickel (Ni) that affected some enzymes in the seed such as $\alpha$-amylase, protease and ribonuclease, inducing a decrease in the time of germination [93]. Also, lead $(\mathrm{Pb})$ delayed radical protrusion through a disturbed carbohydrates metabolism, where the activity of enzymes such as $\alpha$-amylases, $\beta$-amylases, acid invertases and acid phosphatases declined [94].

Kalai et al. [95] observed in barley (Hordeum vulgare L.) seeds a decrease in the activities of $\alpha$-amylase, acid phosphatase and alkaline phosphatase in the endosperm after the application of $\mathrm{Cd}$ $(100 \mu \mathrm{M})$ and $\mathrm{Cu}(500 \mu \mathrm{M})$. The metals diminished soluble sugars and proline contents affecting radicle growth. Similarly, in cowpea (Vigna sinensis (L.) savi ex Hassk) seeds, amylase activity and the total amount of soluble sugars were decreased after treatment with different concentrations of $\mathrm{Cr}$, disturbing germination [96].

Enzymes involved in glycolysis could be modified by heavy metals, as with Cd, that significantly increased alcohol dehydrogenase in the seeds of pea (Pisum sativum L.) [97] or decreased enolases in the seeds of rice, maize, and Arabidopsis [88], affecting the main process of energy supply for seed germination, the glycolysis. By contrast, some mechanisms have been described in plants to cope with heavy metal stress, improving the development of their seeds. Thus, genotypes of transgenics Arabidopsis plants resistant to $\mathrm{Cd}$ showed an increased expression of genes involved in the glutathione synthesis [98].

Finally, it is worth mentioning that in other types of soils such as alkaline soils, $\mathrm{Ca}^{2+}$ is the dominant cation and the germination process is affected by this ion [99]. Although an excess of $\mathrm{Ca}^{2+}$ may delay germination, it has not been found that this ion may induce dormancy or kill the seed [100], as takes place with heavy metals. Also, the accumulation of microplastics can result in other forms of soil contamination. The seed germination of Lepidium sativum plants were affected by microplastics in the short-term, inducing a delay in the process which pointed out the impact of nano-and microplastics 
on the terrestrial systems [101]. Further investigation concerning the effect of microplastics on plant germination and development are necessary to measure the environmental impact of these particles.

\section{Mineral Seed Biofortification to Cope with Nutrient Deficiencies}

Seed biofortification has been applied to increase the level of proteins and fatty acids in cereals and oilseed plants [102]. However, metal ions can be remobilized from leaves to developing grains via phloem tissues, which create the challenge of obtaining mineral biofortified seeds. In fact, in the world population, micronutrient deficiencies are common and cause serious problems in human health [102]. Primarily, Fe and Zn deficiencies are usual in countries where a cereal-based diet is predominant [103]. Over $60 \%$ of the world's population are Fe deficient and over $25 \%$ are $\mathrm{Zn}$ deficient [104]. The problem is aggravated in arid and semi-arid regions, as a result of unfavorable conditions such as the low soil water content, high $\mathrm{pH}$ levels, the presence of carbonates or the low organic material [105]. An increase in carbon dioxide as a result of climate change conditions may intensify some micronutrient deficiencies. In fact, several crops had lower Fe content when they were grown under increased $\mathrm{CO}_{2}$ atmosphere [106].

Therefore, in addition to improving food security through enhanced seed vigor and production, the mineral enrichment of seeds may also help in coping with malnutrition problems.

It has been suggested that the selection of genotypes with higher ion acquisition efficiencies improves seed ion accumulation. Thus, in two Zn-efficient genotypes of Phaseolus vulgaris, with an elevated capacity to uptake $\mathrm{Zn}$ from Zn-deficient soils, a higher $\mathrm{Zn}$ level in the seeds was observed than in the seeds of a Zn-inefficient genotype $[107,108]$. Also, in different locations in Turkey, it was demonstrated that increased levels of $\mathrm{Zn}$ in cereals were a consequence of a higher $\mathrm{Zn}$ uptake by the plant [109], and not because of a higher remobilization of the ion. Therefore, the allocation of the desired ion to edible parts of the plant as seeds is sometimes difficult and it depends on the genotype and the specific ion. These genotype distinctions could be due to an accelerated leaf senescence that is linked to micronutrient accumulation in grains [110]. Similarly, different genetic sources of lentils were used in breeding and crop improvement programs, with distinct levels of $\mathrm{Ca}, \mathrm{Zn}$ and Fe concentrations in the lentil seeds [111].

Difficulties in seed biofortification include a lack of knowledge about how minerals are remobilized into seeds and which genes are suitable for modification [112]. In rice seeds, for example, during germination, Zn flow had a higher dynamic compared to Fe and $\mathrm{Mn}$, changing these minerals and their localization into the seed tissues during the distinct germination phases [113].

Alternative to agronomic biofortification (by soil or foliar application), genetic biofortication offers new tools based on different approaches; such as to increase ion uptake or translocation to the grain, enhance specialization of the ion storage toward endosperm, or decrease antinutrition as phytates with increased ion bioavailability. Traditional breeding programs can be developed after the observation that in 939 rice genotypes, the range of Fe concentration varied from 7.5 to $24.4 \mathrm{mg}$ $\mathrm{kg}{ }^{1}{ }^{1}[114]$. However, these programs are limited due to the natural variation of Fe content in the rice selected germplasm and because genetic biofortification has been used to increase Fe levels in the grains. Ectopic overexpression (OE) of the soybean SoyFerH1and or endemic TaFer1-A gene rice and wheat, respectively, increased Fe content in endosperm. Similar OE lines with different genetic backgrounds (Swarna, IR68144, BR29, IR64, M12) were constructed using distinct promoters (OsGluB1, OsGtbl, CluB1, GluB4, OsG1b), leading to stable lines [115]. Other genes have been used as targets to increase Fe content in rice, thus the ferritin gene (OsFer2) involved in Fe transport, OE of OsYSL and NAS gene subfamilies involved in Fe uptake, were also overexpressed to produce Fe enriched lines [116].

Also, transgenic barley plants overexpressing a $\mathrm{Zn}$ transporter increased the content of $\mathrm{Zn}$ in their seeds. In addition, the construction of transgenic rice plants expressing the refre1/372 gene together with the promoter OsIRT1 increased the tolerance to low Fe availability [117]. But, because the antinutrient phytic acid may inhibit the bioavailability of the $\mathrm{Fe}$ and $\mathrm{Zn}$ in mammals, the reduction 
of the phytate/mineral cation molar ratio is also a key issue. Alternative approaches to reduce $\mathrm{Zn}$ and Fe deficiencies have been realized; such as the promotion of the activity of phytase protein or the increment of its gene expression [118].

However, although low phytic acid (lpa) lines have been developed for different crops [119] and even in maize plants, a 90\% reduction of phytate has been achieved, a decrease in the germination was also observed compared to the wild type [120]. Similarly, in soybean mutants, seedling emergence was inhibited [121].

It is also worth considering, in a grain biofortification program, the knowledge of ion distribution in the seed tissues [122]. For example, in wheat grains, Fe is lost during milling and processing since this element is mainly localized on the outer layers of the seed [123]. Thus, enriched Fe endosperm varieties are desirable in order to enhance the content of $\mathrm{Fe}$ in wheat flour. The use of such techniques as synchrotron-based micro-X-ray fluorescence (micro-XRF) and micro-proton induced X-ray emission (micro-PIXE) allow for describing the localization of Fe and P in wheat grains [30]. The authors concluded that the development of high yielding wheat cultivars led to the selection of varieties with less Fe in their endosperms, where Fe was displaced from the maternal tissue to the filial tissue aleurone.

In a recent review, a combination of different strategies was suggested to increase micronutrient content in grains [124]. Thus, an adequate environment, a balanced fertilization, better genotypes together with correct micronutrient foliar applications may result in microelement enriched grains with better strategies to cope with abiotic stresses. In any case, the use of different biofortification strategies affecting gene expression, such as an increment of the amount of metal chelators or metal transporters in grains has been enhanced. Among these approaches, a multiple gene overexpression strategy has been described in order to increase Fe and $\mathrm{Zn}$ levels in rice. Thus, in the expression of exogenous genes such as PvFER (an endosperm storage gene) the chelator AtNAS1 gene and AtNRAMP3 (an intracellular ion stores), the content of Fe was strongly increased in greenhouse cultivated rice [125].

The genome editing tool CRISPR Cas9 (Clustered Regulatory Interspaced Palindromic Repeats) may be also used to produce enriched ion grains. The base of this tool could be focused in the exploitation of some genes such as the VIT gene, a vascular Fe transporter, the interruption of which may avoid the transport of Fe to the leaves in favor of grain filling [126]. However, in spite of the new genetic biofortification assays, the seed morphology and physiology as well as mineral distribution has to be considered for this to be successful.

Finally, biofortification may help to cope with some abiotic stresses. In rice, selenium (Se) biofortification combined with seed priming alleviated saline stress $(\mathrm{NaCl} 150 \mathrm{mM})$ through an increase of the $\mathrm{Na}^{+} / \mathrm{H}^{+}$antiporter, OsNHX1 [127]. Similarly, Se protected sorghum and wheat grain plants of high temperature stress [128]. In maize, Se activated different genes are involved in the abiotic stress response such as the PSY (phytoene synthase) and SDH (sorbitol dehydrogenase) genes, responsible for osmolyte maintenance under drought. In addition, Se supplies increased K concentrations in maize grains contributing to osmotic adjustment also under drought conditions [129].

Important advances in biotechnology and molecular tools have led to new interventions for crop ion biofortification. More field trials are necessary in order to corroborate greenhouse results, since different environments may condition the final protein response. In addition, safety protocols have to be established for the new crops and to ensure a lack of possible toxicity, allergenicity, environmental contamination. Compositional analysis, pest management and seed vigor should also be monitored.

\section{Seed Genes to Cope with Abiotic Stress}

Seed germination has been used as a plant developmental stage to study the effect of different abiotic stresses on the molecular mechanisms involved in the plant response.

The transition from different phases of germination is closely related to ROS signaling, hormonal and environmental changes including an important role of genes involved in the signaling cascade of ABA: ABI3 (ABA INSENSITIVE 3), ABI5 (ABA INSENSITIVE 5), gibberellins: RGL2 (REPRESSOR OF GA1-3 LIKE 2), and ethylene: EIN2 (ETHYLENE INSENSITIVE 2) [130]. 
In a recent review, modifications in the expression of $\mathrm{ABA}$ and gibberellin (GA) biosynthesis genes affecting seed germination under abiotic stress were described, as well as the transcription factors involved in these genes' regulation [131]. The authors pointed out the importance of the crosstalk pathways of these and other phytohormones at different molecular targets with synergic or antagonist effects. Thus, the expression of the gene NCED, involved directly in the synthesis of ABA, had an important effect in the response to abiotic stress but also in the seed germination and maturation, highlighting the crosslink between both events [132]. Alterations in the transporters that allow for ABA storage and translocation were also observed under drought [133] or salt and osmotic stress $[134,135]$. Also, the GA signaling pathway promoted DELLA protein degradation that formed a complex with the transcription factor DOF6, resulting in a positive effect on genes such as RGL2, involved in seed germination response under salt stress [136]. In a similar way, a gene encoding an Arabidopsis expansin isoform protein, EXP2, implicated in cell wall modifications, was altered under salt and osmotic stress through the effect of the GA signaling pathway on DELLA repressors. This modification induced changes in seed coat extensibility during germination [137].

One of the first responses to stress is the increase of reactive oxygen species (ROS). Genes involved in the defence mechanisms against ROS accumulation has been widely identified in plant tissues, but there is less information concerning to the genes and transcription factors involved in the antioxidant response in seeds under abiotic stress. During germination, postgermination and seed development processes, a high metabolism and ROS production have been reported as normal seed activity modulation, with the maintenance of ROS homeostasis and regulation of seed metabolism through the crosstalk of GA and/or ABA pathways [138].

However, the balance between ROS production and scavenging may be affected by abiotic stresses, causing DNA damage and reducing seed quality [139]. In order to cope with stress, different genes modify their expression, protecting plant seeds. Previous studies using $A$. thaliana mutants described the positive effect of tocopherol-related gene synthesis preventing oxidative stress damage, with the increase of seed longevity and germination [140]. Similarly, the hormone 28-homobrassinolide (28-HBL), belonging to brassinosteroids (BRs), was overexpressed under chrome toxicity, improving the antioxidant response in seeds of Raphanus sativus L. [141]. Sulfur metabolism was also regulated under heavy metal toxicity in seeds with genes involved in the expression of ATP sulfurylase (APS), adenosine $5^{\prime}$ phosphosulfatereductase (APR), Ser acetyl, transferase (SAT) and O-acetyl-ser (thiol)-lyase (OASTL), up-regulated in order to confer seed stress tolerance [142].

In soybean seed coat, the transcriptional response to abiotic stresses including drought, elevated $\mathrm{O}_{3}$ concentration, or elevated temperature was evaluated during the pod filling developmental stage and few genes were affected by drought and ozone [143]. However, the transcriptomic analysis revealed that 1576 genes were differentially expressed at high temperatures. Among them, an increased expression of the MCM gene family, involved in DNA replication, was observed. The authors proposed that this increased DNA replication, together an elevated cell cycle activity, was a response to the acceleration of seed development under high temperature. The fact that similar genes were not affected by distinct stresses, showed the importance of the stress nature as well as its duration and intensity in the seed sensing unfavorable environments.

Therefore, the response to different abiotic stresses in the seeds is a complex network in which different gene expression and the regulation of protein turnover are involved [144]. Genomic information about the transcription factors that regulate the related-stress gene is still poor. It has been recently identified in Arabidosis thaliana, a nuclear protein, ATR7, as a novel regulator of oxidative stress that controlled oxidative and abiotic stress-related genes in the seeds [145]. Also, Xi et al. [146] identified the At2S3 promoter as responsible for the overexpression of antioxidant proteins (Mn-SOD and total CAT activities) in seed related organs such as siliques, mature seeds, and early seedlings. The identification of transcription factors involved in multiple abiotic stress responses should be more effective for achieving strategies that make more resistant seeds to stresses. 
It is worth mentioning the recent CRISPR Cas9 genome editing technology that was used to improve the tolerance to abiotic stress of many grain plants such as wheat [147], maize [148], and sorghum $[149,150]$ and rice $[151,152]$. In addition, this tool has been applied to improve seed size and abiotic stress tolerance, both important agronomic traits in crops. Using Arabidopsis triple AITRs (ABA-induced transcription repressors) mutants, with enhanced tolerance to drought and salt, CRISPR Cas9 was used for editing DPA4 and SOD7 genes (negatively involved in seed size) in these mutants [10]. The result was a plant producing large seeds and tolerant to drought and salinity.

Finally, different physiological studies have revealed more than one hundred physiological traits involved in the response of plant to abiotic stress. Seed traits have a great importance in seedling vigor, especially in root quality and development, that were highly correlated with seed vigor and may condition subsequent plant response to abiotic stress [153]. Therefore, an analysis of how seed traits are conditioned by the ion homeostasis and their relation to the seedling response to abiotic stress may help the production of tolerant germplasms with adequate yields.

\section{Future Perspectives}

Seed germination is a very critical step for the establishment of the seedling. The maternal environment as well as the effects induced during the embryo formation may condition further seed traits such as size and quality. In this sense, abiotic stress may induce a poor germination and cause irreversible damage to the seed tissues. The use of new image techniques has elucidated how the efflux of ions from the maternal tissues to the seed coat occurs, allowing deeper knowledge of ion redistribution into the seed coat, which may influence at the same time, the transport of other substances.

Under abiotic stress, hormone regulation may play a decisive role in the normal function of seed metabolism, allowing hydration and radicle emersion during the response to stress. However, few transporters involved in these processes have been identified, as well as the mechanisms that regulate these ion fluxes and the hormone-ion correlation. In addition, few transcription factors controlling the gene involved in these hormone-dependent processes have been described.

Nowadays, anthropological activities produce the release of heavy metals in natural resources, which is a serious worldwide problem. The presence of these metals in soils may affect biodiversity through a reduction of seed germination. In environments with heavy metal contamination further exploration of the role of tonoplast transporters is needed, as targets of the ion transport signal through the plasma membrane. Also, although membrane transporters in plant tissues have been widely studied, it is not clear if metal transporter genes may participate in ion homeostasis in the seed tissues and how their distribution into them takes place. Therefore, more studies concerning the genetic elements that may help seeds to cope with soil heavy metals stress are needed in order to achieve optimal germination rates.

The importance of macro and micro nutrients has been widely studied in plants, although the effect of their presence, transport and redistribution within the seeds and the subsequent consequences on seedling development is still poorly understood. Increased understanding in this topic is a key issue for improving yields and stress tolerance in agriculture, in addition to coping with plants and human micronutrient deficiencies. Thus, although seed osmopriming has been proven as a presowing treatment that induces better seedling emergence and yields, especially under abiotic stress conditions, the molecular mechanisms underlying the germinative metabolism stimulated by osmopriming are not well known. Seed priming may improve postharvest seed quality, but their effects on the vigor of the plant and seed yield are still poorly documented. Transition ion accumulation in edible seeds as cereals is a key issue to combat micronutrient deficiencies in human health by gaining nutrients grain plants. An adequate nutrient balance is also necessary for plant survival and growth. However, there are no clear patterns for seed biofortification and genotype, which needs to be clarified in future breeding planning. 
Under changing environmental conditions, understanding ion homeostasis in the seeds during distinct germination stages as well as during embryo formation in the plant may contribute to developing new strategies to improve seed quality and resilience against unfavorable environments.

Finally, the introduction of novel genetic tools as CRISPR/Cas9 will allow for exploiting genes conferring important agronomic traits such as seed size (yield) and abiotic stress resistance, as it has already been introduced in some of the main grain plants, in order to improve future breeding programs and commercial purposes.

Author Contributions: Conceptualization, M.d.C.M.-B, M.J.V. and J.A.F. (Juan A. Fernández); methodology, M.d.C.M.-B.; validation, M.J.V., C.E.-G., S.B., and J.O.; formal analysis, E.C. and J.J.M.; investigation, C.E.-G, E.C., J.O., J.A.F. (José A. Franco); resources, M.d.C.M.-B, M.J.V., J.J.M. and S.B. data curation, writing-original draft preparation, M.d.C.M.-B, C.E.-G, E.C., J.O., M.J.V., J.A.F. (José A. Franco), S.B., J.J.M and J.A.F. (Juan A. Fernández) writing-review and editing, M.d.C.M.-B., C.E.-G. and J.A.F. (Juan A. Fernández); visualization, C.E.-G, M.J.V., J.A.F. (José A. Franco), S.B., and J.J.M.; supervision, M.d.C.M.-B and J.A.F. (Juan A. Fernández); project administration, M.d.C.M.-B, M.J.V., E.C, J.O., S.B., J.A.F. (José A. Franco), J.A.F. (Juan A. Fernández) and J.J.M. All authors have read and agreed to the published version of the manuscript.

Funding: This research received no external funding

Acknowledgments: The Funding from the following source is acknowledged: Department of Agronomy Engeneering of Universidad Politécnica de Cartagena.

Conflicts of Interest: The authors declare that the research was conducted in the absence of any commercial or financial relationships that could be construed as a potential conflict of interest.

\section{References}

1. Daszkowska-Golec, A. Arabidopsis seed germination under abiotic stress as a concert of action of phytohormones. OMICS J. Integr. Biol. 2011, 15, 763-774. [CrossRef]

2. Galland, M.; He, D.; Lounifi, I.; Arc, E.; Clément, G.; Balzergue, S.; Huguet, S.; Cueff, G.; Godin, B.; Collet, B.; et al. An Integrated "Multi-Omics" Comparison of Embryo and Endosperm Tissue-Specific Features and Their Impact on Rice Seed Quality. Front. Plant. Sci. 2017, 8, 1984. [CrossRef]

3. Wen, D.; Xu, H.; Xie, L.; He, H.; Hou, H.; Zhang, C. A loose endosperm structure of wheat seed produced under low nitrogen level promotes early germination by accelerating water uptake. Sci. Rep. 2017, 7, 1-11. [CrossRef]

4. Eckert, C.; Offenborn, J.N.; Heinz, T.; Armarego-Marriott, T.; Schultke, S.; Zhang, C.; Hillmer, S.; Heilmann, M.; Schumacher, K.; Bock, R.; et al. The vacuolar calcium sensors CBL2 and CBL3 affect seed size and embryonic development in Arabidopsis thaliana. Plant J. 2014, 78, 146-156. [CrossRef]

5. Gómez-Ramírez, A.; López-Santos, C.; Cantos, M.; García, J.L.; Molina, R.; Cortino, J.; Espinós, J.P.; González-Elipe, A.R. Surface chemistry and germination improvement of Quinoa seeds subjected to plasma activation. Sci. Rep. 2017, 7, 5924. [CrossRef]

6. Kim, S.G.; Lee, A.K.; Yoon, H.K.; Park, C.M. A membrane-bound NAC transcription factor NTL8 regulates gibberellic acid-mediated salt signaling in Arabidopsis seed germination. Plant J. 2009, 55, 77-88. [CrossRef]

7. Guo, J.; Wang, J.; Xi, L.; Huang, W.D.; Liang, J.; Chen, J.G. RACK1 is a negative regulator of ABA responses in Arabidopsis. J. Exp. Bot. 2009, 60, 3819-3833. [CrossRef]

8. Zhu, Q.; Zhang, J.; Gao, X.; Tong, J.; Xiao, L.; Li, W.; Zhang, H. The Arabidopsis AP2/ERF transcription factor RAP2.6 participates in ABA, salt and osmotic stress responses. Gene 2010, 457, 1-12. [CrossRef]

9. Li, W.Y.F.; Wong, F.L.; Tsai, S.N.; Phang, T.H. Tonoplast-located GmCLC1 and GmNHX1 from soybean enhance $\mathrm{NaCl}$ tolerance in transgenic bright yellow (BY)-2 cells. Plant Cell Environ. 2006, 29, 1122-1137. [CrossRef]

10. Chen, S.; Zhang, N.; Zhang, Q.; Zhou, G.; Tian, H.; Hussain, S.; Ahmed, S.; Wang, T.; Wang, S. Genome editing to integrate seed size and abiotic stress tolerance traits in Arabidopsis reveals a role for DPA4 and SOD7 in the regulation of inflorescence architecture. Int. J. Mol. Sci. 2019, 20, 2695. [CrossRef]

11. Bihmidine, S.; Hunter, C.T.; Johns, C.E.; Koch, K.E.; Braun, D.M. Regulation of assimilate import into sink organs: Update on molecular drivers of sink strength. Front. Plant. Sci. 2013, 177, 1-15. [CrossRef]

12. Thiel, J. Development of endosperm transfer cells in barley. Front. Plant. Sci. 2014, 5, 1-12. [CrossRef] 
13. White, P.J.; Veneklaas, E.J. Nature and nurture: The importance of seed phosphorus content. Plant Soil 2012, 357, 1-8. [CrossRef]

14. Moon, S.S.; Bhande, M.H.; Gajbhiye, R.P. Effect of Nitrogen and Phosphorus on Seed Quality and Seed Yield of Gaillardia. Int. J. Curr. Microbiol. Appl. Sci. 2018, 6, 1279-1283.

15. Raboy, V. Approaches and challenges to engineering seed phytate and total phosphorus. Plant Sci. 2009, 177, 281-296. [CrossRef]

16. Li, Y.T.; Zhang, J.; Zhang, X.; Fan, H.M.; Gu, M.; Qu, H.Y.; Xu, G.H. Phosphate transporter OsPht1; 8 in rice plays an important role in phosphorus redistribution from source to sink organs and allocation between embryo and endosperm of seeds. Plant Sci. 2015, 230, 23-32. [CrossRef]

17. Zhang, F.; Sun, Y.F.; Pei, W.X.; Jain, A.; Sun, R.; Cao, Y.; Wu, X.; Jiang, T.; Zhang, L.; Fan, X.; et al. Involvement of OsPht1; 4 in phosphate acquisition and mobilization facilitates embryo development in rice. Plant J. 2015, 82, 556-569. [CrossRef]

18. Shukla, V.; Kaur, M.; Aggarwal, S.; Bhati, K.K.; Kaur, J.; Mantri, S.; Pandey, A.K. Tissue specific transcript profiling of wheat phosphate transporter genes and its association with phosphate allocation in grains. Sci. Rep. 2016, 6, 39293. [CrossRef]

19. Zhang, W.H.; Zhou, Y.; Dibley, K.E.; Tyerman, S.D.; Furbank, R.T.; Patrick, J.W. Nutrient loading of developing seeds. Funct. Plant Biol. 2007, 34, 314-331. [CrossRef]

20. Vogiatzaki, E.; Baroux, C.; Jung, J.Y.; Poirier, Y. PHO1 exports phosphate from the chalazal seed coat to the embryo in developing Arabidopsis seeds. Curr. Biol. 2017, 27, 2893-2900. [CrossRef] [PubMed]

21. Patrick, J.W.; Offler, C.E. Compartmentation of transport and transfer events in developing seeds. J. Exp. Bot. 2001, 52, 551-564. [CrossRef]

22. Agrawal, G.K.; Hajduch, M.; Graham, K.; Thelen, J.J. In-depth investigation of the soybean seed-filling proteome and comparison with a parallel study of rapeseed. Plant Physiol. 2008, 148, 504-518. [CrossRef]

23. Inoue, H.; Higuchi, K.; Takahashi, M.; Nakanishi, H.; Mori, H.; Nishizawa, N.K. Three rice nicotianamine synthase genes, OsNAS1, OsNAS2, and OsNAS3 are expressed in cells involved in long-distance transport of iron and differentially regulated by iron. Plant J. 2003, 36, 366-381. [CrossRef]

24. Le Jean, M.; Schikora, A.; Mari, S.; Briat, J.F.; Curie, C. A loss-offunction mutation in AtYSL1 reveals its role in iron and nocotianamine seed loading. Plant J. 2005, 44, 769-782. [CrossRef]

25. Waters, B.M.; Chu, H.H.; DiDonato, R.J.; Roberts, L.A.; Eisley, R.B.; Lahner, B.; Salt, D.E.; Walker, E.L. Mutations in Arabidopsis yellow stripe-like1 and yellow stripe-like3 reveal their roles in metal homeostasis and loading of metal ions in seeds. Plant Physiol. 2006, 141, 1446-1458. [CrossRef]

26. Kruger, C.; Berkowitz, O.; Stephan,U.W.; Hell, R. A metal-binding member of the late embryogenesis abundant protein family transports iron in the phloem of Ricinus communis L. J. Biol. Chem. 2002, 277, 25062-25069. [CrossRef]

27. Tabe, L.M.; Droux, M. Sulfur assimilation in developing lupin cotyledons could contribute significantly to the accumulation of organic sulfur reserves in the seed. Plant. Physiol. 2001, 126, 176-187. [CrossRef]

28. Awazuhara, M.; Fujiwaa, T.; Hayashi, H.; Watanabe-Takahashi, A.; Takahashi, H.; Saito, K. The function of SULTR2;1 sulfate transporter during seed development in Arabidopsis thaliana. Physiol. Plant. 2005, 125, 95-105. [CrossRef]

29. Zuber, H.; Poignavent, G.; Le Signor, C.; Aime, D.; Vieren, E.; Tadla, C.; Lugan, R.; Belghazi, M.; Labas, V.; Santoni, A.L.; et al. Legume adaptation to sulfur deficiency revealed by comparing nutrient allocation and seed traits in Medicago truncatula. Plant J. 2013, 76, 982-996. [CrossRef]

30. Singh, S.P.; Vogel-Mikuš, K.; Arčon, I.; Vavpetič, P.; Jeromel, L.; Pelicon, P.; Kumar, J.; Tul, R. Pattern of iron distribution in maternal and filial tissues in wheat grains with contrasting levels of iron. J. Exp. Bot. 2013, 64, 3249-3260. [CrossRef]

31. Tan, L.; Chen, S.; Wang, T.; Dai, S. Proteomic insights into seed germination in response to environmental factors. Proteomics 2013, 13, 1850-1870. [CrossRef] [PubMed]

32. Nagy, R.; Grob, H.; Weder, B.; Green, P.; Klein, M.; Frelet-Barrand, A.; Schjoerring, J.K.; Brarley, C.; Martinoia, E. The Arabidopsis ATP-binding cassette protein AtMRP5/AtABCC5 is a high affinity inositol hexakisphosphate transporter involved in guard cell and phytate storage. J. Biol. Chem. 2009, 284, 33614-33622. [CrossRef] [PubMed]

33. Williams, S.; Gillaspy, G.E.; Perera, I.Y. Biosynthesis and possible functions of inositol pyrophosphates in plants. Front. Plant. Sci. 2015, 6, 67. [CrossRef] [PubMed] 
34. Belmonte, M.F.; Kirkbride, R.C.; Stone, S.L.; Pelletier, J.M.; Bui, A.Q.; Yeung, E.C.; Hashimoto, M.; Fei, J.; Harada, C.M.; Munoz, M.D.; et al. Comprehensive developmental profiles of gene activity in regions and subregions of the Arabidopsis seed. Proc. Natl. Acad. Sci. USA 2013, 110, 435-444. [CrossRef]

35. Eroglu, S.; Giehl, R.F.H.; Meier, B.; Takahashi, M.; Terada, Y.; Ignatiev, K. Metal tolerance protein 8 mediates manganese homeostasis and iron re-allocation duringseed development and germination. Plant Physiol. 2017, 174, 1633-1647. [CrossRef]

36. Eroglu, S. Metal transport in the developing plant seed. Adv. Bot. Res. 2018, 87, 91-113.

37. Mandizvo, T.; Odindo, A.O. Seed mineral reserves and vigour of Bambara groundnut (Vigna subterranean L.) landraces differing in seed coat colour. Heliyon 2019, 5, e01635. [CrossRef]

38. Brinch-Pedersen, H.; Sørensen, L.D.; Holm, P.B. Engineering crop plants: Getting a handle on phosphate. Trends Plant. Sci. 2002, 7, 118-125. [CrossRef]

39. Waters, B.M.; Grusak, M.A. Whole-plant mineral partitioning throughout the life cycle in Arabidopsis thaliana ecotypes Columbia, Landsberg erecta, Cape Verde Islands, and the mutant line ysl1ysl3. New Phytol. 2008, 177, 389-405. [CrossRef]

40. Roschzttardtz, H.; Conéjéro, G.; Curie, C.; Mari, S. Identification of the endodermal vacuole as the iron storage compartment in the Arabidopsis embryo. Plant. Physiol. 2009, 151, 1-10. [CrossRef]

41. Klein, M.A.; Grusak, M.A. Identification of nutrient and physical seed trait QTL in the model legume Lotus japonicus. Genome 2009, 52, 677-691. [CrossRef]

42. Kim, S.A.; Punshon, T.; Lanzirotti, A.; Li, L.; Alonso, J.M.; Ecker, J.R.; Kaplan, J.; Guerinot, M.L. Localization of iron in Arabidopsis seed requires the vacuolar membrane transporter VIT1. Science 2006, 314, 1295. [CrossRef] [PubMed]

43. Ariza-Nieto, M.; Blair, M.W.; Welch, R.M.; Glahn, R.P. Screening of iron bioavailability patterns in eight bean (Phaseolus vulgaris L.) genotypes using the Caco-2 cell in vitro model. J. Agric. Food Chem. 2007, 55, 7950-7956. [CrossRef] [PubMed]

44. Kandari, L.S.; Kulkarni, M.G.; Van Staden, J. Effect of nutrients and smoke solutions on seed germination and seedling growth of tropical soda apple (Solanum viarum). Weed Sci. 2011, 59, 470-475. [CrossRef]

45. Karimmojeni, H.; Rashidi, B.; Behrozi, D. Effect of different treatments on dormancy-breaking and germination of perennial pepperweed (Lepidium latifolium) (Brassicaceae). Aust. J. Agric. Eng. 2011, 2, 50-55.

46. Kołodziejek, J. Effect of seed position and soil nutrients on seed mass, germination and seedling growth in Peucedanum oreoselinum (Apiaceae). Sci. Rep. 2017, 7, 1-11. [CrossRef]

47. Hendrix, S.D. Variation in seed weight and its effect on germination in Pastinaca sativa L. (Umbelliferae). Am. J. Bot. 1984, 71, 795-802. [CrossRef]

48. Zampar-Toledo, M.; Arroyo-Garcia, R.; Merlin, A.; Fernandes, D.M. Seed germination and seedling development of white oat affected by silicon and phosphorus fertilization. Sci. Agric. 2011, 68, 18-23. [CrossRef]

49. Inácio-Cardoso, A.I.; de Toledo, M.; Oliveira, F.; Gomes, P. Phosphate fertilization on production and quality of cauliflower seeds. Ciência Rural 2016, 46, 1337-1343. [CrossRef]

50. Yang, W. Effect of nitrogen, phosphorus and potassium fertilizer on growth and seed germination of Capsella bursa-pastoris (L.) Medikus. J. Plant Nutr. 2018, 41, 636-644. [CrossRef]

51. Planes, M.D.; Niñoles, R.; Rubio, L.; Bissoli, G.; Bueso, E.; García-Sánchez, M.J.; Alejandro, S.; Gonzalez-Guzmán, M.; Hedrich, R.; Rodriguez, P.L.; et al. A mechanism of growth inhibition by abscisic acid in germinating seeds of Arabidopsis thaliana based on inhibition of plasma membrane $\mathrm{H}^{+}$-ATPase and decreased cytosolic pH, $\mathrm{K}^{+}$, and anions. J. Exp. Bot. 2015, 66, 813-825. [CrossRef]

52. Park, J.; Yoo, J.H.; Depuydt, S.; Oh, J.W.; Yo, Y.M.; Kim, K.; Brown, M.T.; Han, T. The sensitivity of a hydroponic lettuce root elongation bioassay to metals, phenol and wastewaters. Ecotoxicol. Environ. Saf. 2016, 126, 147. [CrossRef] [PubMed]

53. Kundrát, J.T.; Gyulai, I.; Simon, E.; Mizsei, E.; Braun, M.; Tóthmérész, B. Study of the effects of high levels of nutrients on seed germination and root elongation. Pol. J. Environ. Stud. 2017, 26, 1-6. [CrossRef]

54. Suwa, R.; Jayachandran, K.; Nguyen, N.T.; Boulenouar, A.; Fujita, K.; Saneoka, H. Barium toxicity effects in soybean plants. Arch. Environ. Contam. Toxicol. 2008, 55, 397. [CrossRef] [PubMed]

55. Chen, C.; Huang, D.; Liu, J. Functions and toxicity of nickel in plants: Recent advances and future prospects. Clean-Soil Air Water 2009, 37, 304. [CrossRef] 
56. Brunel-Muguet, S.; D’Hooghe, P.; Bataillé, M.P.; Larre, C.; Kim, T.H.; Trouverie, J.; Avice, J.C.; Etienne, P.; Dürr, C. Heat stress during seed filling interferes with sulfur restriction on grain composition and seed germination in oilseed rape (Brassica napus L.). Front. Plant Sci. 2015, 6, 213. [CrossRef] [PubMed]

57. Iqbal, M.; Ashraf, M. Gibberellic acid mediated induction of salt tolerance in wheat plants: Growth, ionic partitioning, photosynthesis, yield and hormonal homeostasis. Environ. Exp. Bot. 2013, 86, 76-85. [CrossRef]

58. De Oliveira, A.B.; Gomes-Filho, E. How are germination performance and seedling establishment under abiotic stress improved by seed priming? A review. Aust. J. Crop Sci. 2016, 10, 1047-1051. [CrossRef]

59. Di Girolamo, G.; Barbanti, L. Treatment conditions and biochemical processes influencing seed priming effectiveness. Ital. J. Agron. 2012, 7, 8-18. [CrossRef]

60. Jisha, K.C.; Vijayakumari, K.; Puthur, J.T. Seed priming for abiotic stress tolerance: An overview. Acta Physiol. Plant. 2013, 35, 381-1396. [CrossRef]

61. Lutts, S.; Benincasa, P.; Wojtyla, L.; Kubala, S.; Pace, R.; Lechowska, K.; Quinet, M.; Garnczarska, M. Seed priming: New comprehensive approaches for an old technique. In New Challenges in Seed Biology—Basic and Translational Research Driving Seed Technology; IntechOpen: London, UK, 2016; ISBN 978-953-51-2659-1.

62. Ibrahim, E.A. Seed priming to alleviate salinity stress in germinating seeds. J. Plant Physiol. 2016, 192, 38-46. [CrossRef] [PubMed]

63. Farooq, M.; Basra, S.M.A.; Hafeez, K. Seed invigoration by osmohardening in coarse and fine rice (Oryza sativa L.). Seed Sci. Technol. 2006, 34, 181-187. [CrossRef]

64. Zhou, D.; Moxin Xiao, M. Specific ion effects on the seed germination of sunflower. J. Plant Nutr. 2010, 33, 255-266. [CrossRef]

65. Lechowska, K.; Kubala, S.; Wojtyla, Ł.; Nowaczyk, G.; Quinet, M.; Lutts, S.; Garnczarska, M. New insight on water status in germinating Brassica napus seeds in relation to priming-improved germination. Int. J. Mol. Sci. 2019, 20, 540. [CrossRef]

66. Oliveira, A.B.; Prisco, J.T.; Enéas-Filho, J.; Gomes-Filho, E. Salinity effects on germination and establishment of sorghum seedlings from artificially aged and primed seeds. J. New Seeds 2010, 11, 399-411. [CrossRef]

67. Kubala, S.; Wojtyla, Ł.; Quinet, M.; Lechowska, K.; Lutts, S.; Garnczarska, M. Enhanced expression of the proline synthesis gene P5CSA in relation to seed osmopriming improvement of Brassica napus germination under salinity stress. J. Plant Physiol. 2015, 183, 1-12. [CrossRef]

68. Zheng, M.; Tao, Y.; Hussain, S.; Jiang, Q.; Peng, S.; Huang, J.; Cui, K.; Nie, L. Seed priming in dry direct-seeded rice: Consequences for emergence, seedling growth and associated metabolic events under drought stress. Plant. Growth Regul. 2015, 78, 167-178. [CrossRef]

69. Espanany, A.; Fallah, S.; Tadayyon, A. Seed priming improves seed germination and reduces oxidative stress in black cumin (Nigella sativa) in presence of cadmium. Ind. Crops Prod. 2016, 79, 195-204. [CrossRef]

70. Hussain, S.; Khan, F.; Cao, W.; Wu, L.; Mingjian Geng, M. Seed Priming Alters the Production and detoxification of reactive oxygen intermediates in rice seedlings grown under sub-optimal temperature and nutrient supply. Front. Plant Sci. 2016, 7, 439. [CrossRef]

71. Khan, E.; Gupta, M. Arsenic-silicon priming of rice (Oryza sativa L.) seeds influence mineral nutrient uptake and biochemical responses through modulation of Lsi-1, Lsi-2, Lsi-6 and nutrient transporter genes. Sci. Rep. 2018, 8, 10301. [CrossRef]

72. Chiu, K.Y.; Chuang, S.J.; Sung, J.M. Both anti-oxidation and lipid-carbohydrate conversion enhancements are involved in priming-improved emergence of Echinacea purpurea seeds that differ in size. Sci. Hortic. Amst. 2006, 108, 220-226. [CrossRef]

73. Conrtah, U. Molecular aspects of defence priming. Trends Plant Sci. 2011, 16, 524-531. [CrossRef] [PubMed]

74. Liu, N.; Shen, Y.; Huan, B. Osmoregulants involved in osmotic adjustment for differential drought tolerance in different Bentgrass genotypes. J. Am. Soc. Hortic. Sci. 2015, 140, 605-613. [CrossRef]

75. Jafar, M.Z.; Farooq, M.; Cheema, M.A.; Afzal, I.; Basra, S.M.A.; Wahid, M.A.; Azid, T.; Shahid, M. Improving the performance of wheat by seed priming under saline conditions. J. Agric. Crop Sci. 2012, 198, 38-45. [CrossRef]

76. Zhang, Q.; Rue, K. Glycinebetaine seed priming improved osmotic and salinity tolerance in turfgrasses. Hortscience 2012, 47, 1171-1174. [CrossRef]

77. Oliveira, A.B.; Alencar, N.L.M.; Prisco, J.T.; Gomes-Filho, E. Accumulation of organic and inorganic solutes in $\mathrm{NaCl}$-stressed sorghum seedlings from aged and primed seeds. Sci. Agrícola 2011, 68, 632-663. [CrossRef] 
78. Bonilla, I.; El-Hamdaoui, A.; Bolaños, L. Boron and calcium increase Pisum sativum seed germination and seedling development under salt stress. Plant Soil 2004, 267, 97-107. [CrossRef]

79. Zaman, B.U.; Ali, A.; Hyder, S.I.; Arshadullah, M.; Bhatti, S.U. Potassium chloride as a nutrient seed primer to enhance salt-tolerance in maize. Pesqui. Agropecuária Bras. 2012, 47, 1181-1184. [CrossRef]

80. Majda, C.; Khalid, D.; Aziz, A.; Rachid, B.; Badr, A.S.; Lotfi, A.; Mohamed, B. Nutri-priming as an efficient means to improve the agronomic performance of molybdenum in common bean (Phaseolus vulgaris L.). Sci. Total Environ. 2019, 661, 654-663. [CrossRef]

81. Imran, M.; Volker, R.; Neumann, G. Accumulation and distribution of Zn and Mn in soybean seeds after nutrient seed priming and its contribution to plant growth under $\mathrm{Zn}$ and $\mathrm{Mn}$ deficient conditions. J. Plant Nutr. 2017, 40, 695-708.

82. Rehman, A.; Farooq, M.; Naveed, M.; Nawaz, A.; Shahzad, B. Seed priming of Zn with endophytic bacteria improves the productivity and grain biofortification of bread wheat. Eur. J. Agron. 2018, 94, 98-107. [CrossRef]

83. Ghiyasi, S.; Moghaddam, S.S.; Amirnia, R.; Damalas, A.C. Chemical priming with salt and urea improves germination and seedling growth of black cumin (Nigella sativa L.) under osmotic stress. J. Plant Growth Reg. 2019. [CrossRef]

84. Sethy, S.K.; Ghosh, S. Effect of heavy metals on germination of seeds. J. Nat. Sci. Biol. Med. 2013, 4, $272-275$. [PubMed]

85. Divol, F.; Couch, D.; Conéjéro, G.; Roschzttardtz, H.; Mari, S.; Curie, C. The Arabidopsis YELLOW STRIPE LIKE4 and 6 transporters control iron release from the chloroplast. Plant Cell 2013, 25, 1040-1055. [CrossRef]

86. Li, W.; Khan, M.A.; Yamaguchi, S.; Kamiya, Y. Effects of heavy metals on seed germination and early seedling growth of Arabidopsis thaliana. Plant Growth Reg. 2005, 46, 45-50. [CrossRef]

87. Seregin, I.V.; Kozhevnikova, A.D. Distribution of cadmium, lead, nickel, and strontium in imbibing maize Caryopses. Russ. J. Plant Physlol. 2005, 52, 565-569. [CrossRef]

88. Samantaray, S.; Rout, G.R.; Das, P. Role of chromium on plant growth and metabolism. Acta Physiol. Plant. 1998, 20, 201-212. [CrossRef]

89. Ahsan, N.; Lee, D.G.; Lee, S.H.; Kang, K.Y.; Lee, J.J.; Kim, P.J.; Yoon, H.S.; Kim, J.S.; Lee, B.H. Excess copper induced physiological and proteomic changes in germinating rice seeds. Chemosphere 2007, 67, 1182-1193. [CrossRef]

90. Ahsan, N.; Lee, S.H.; Lee, D.G.; Lee, H.; Lee, S.W.; Bahk, J.D.; Lee, B.H. Physiological and protein profiles alternation of germinating rice seedlings exposed to acute cadmium toxicity. Comptes Rendus Biol. 2007, 330, 735-746. [CrossRef]

91. Karmous, I.; Ferjani, E.E.; Chaoui, A. Copper excess impairs mobilization of storage proteins in bean cotyledons. Biol. Trace Elem. Res. 2011, 144, 1251-1259. [CrossRef]

92. Jaouani, K.; Chaoui, A.; Ferjani, E.E. Alteration of cotyledonary globulins and albumins mobilization in pea exposed to cadmium. Sci. Res. Essays 2012, 7, 1273-1279.

93. Ahmad, M.S.; Ashraf, M. Essential roles and hazardous effects of nickel in plants. Rev. Environ. Contam. Toxicol. 2011, 214, 125-167.

94. Singh, H.P.; Kaur, G.; Batish, D.R.; Kohli, R.K. Lead (Pb)-inhibited radicle emergence in Brassica campestris involves alterations in starch-metabolizing enzymes. Biol. Trace Elem. Res. 2011, 144, 1295-1301. [CrossRef] [PubMed]

95. Kalai, T.; Khamassi, K.; Teixeira da Silva, J.A.; Gouia, H.; Bettaieb Ben-Kaab, L. Cadmium and copper stress affect seedling growth and enzymatic activities in germinating barley seeds. Arch. Agron. Soil Sci. 2013, 60, 765-783. [CrossRef]

96. Nath, K.; Singh, D.H.; Shyam, S.; Sharma, Y.K. Effect of chromium and tannery effluent toxicity on metabolism and growth in cowpea (Vigna sinensis L. Saviex Hassk) seedling. Res. Environ. Life Sci. 2008, 1, 91-94.

97. Smiri, M.; Chaoui, A.; Ferjani, E.E. Respiratory metabolism in the embryonic axis of germinating pea seed exposed to cadmium. J. Plant Physiol. 2009, 166, 259-269. [CrossRef] [PubMed]

98. Wang, Y.; Zong, K.; Jiang, L.; Sun, J.; Ren, Y.; Sun, Z.; We, C.; Chen, X.; Cao, S. Characterization of an Arabidopsis cadmium-resistant mutant cdr3-1D reveals a link between heavy metal resistance as well as seed development and flowering. Planta 2011, 233, 697-706. [CrossRef]

99. Ryan, J.; Miyamoto, S.; Stroehlein, J.L. Salt and specific ion effects on germination of four grass. J. Range Manag. 1975, 28, 61-64. [CrossRef] 
100. Guan, B.; Zhou, D.; Zhang, H.; Tian, Y.; Japhet, W.; Wang, P. Germination responses of Medicago ruthenica seeds to salinity, alkalinity, and temperature. J. Arid Environ. 2009, 73, 135-138. [CrossRef]

101. Bosker, T.; Bouwman, L.J.; Brun, N.R.; Behrens, P.; Vijver, M.G. Microplastics accumulate on pores in seed capsule and delay germination and root growth of the terrestrial vascular plant Lepidium sativum. Chemosphere 2019, 226, 774-781. [CrossRef]

102. Garg, M.; Sherma, N.; Sharma, S.; Kapoor, P.; Kumar, A.; Chunduri, V.; Arora, P. Biofortified crops generated by breeding, agronomy, and transgenic approaches are improving lives of millions of people around the world. Front. Nutr. 2018, 5, 12. [CrossRef] [PubMed]

103. Black, R.E.; Allen, L.H.; Bhutta, Z.A.; Caulfield, L.E.; de Onis, M.; Ezzati, M.; Mathers, C.; Rivera, J. Maternal and Child Undernutrition Study Group. Maternal and child undernutrition: Global and regional exposures and health consequence. Lancet 2008, 371, 243-260. [CrossRef]

104. Maret, W.; Sandstead, H.H. Zinc requirements and the risks and benefits of zinc supplementation. J. Trace Elem. Med. Biol. 2006, 20, 3-18. [CrossRef] [PubMed]

105. Gonçalves Junior, A.C.; Nacke, H.; Marengoni, N.G.; Carvalho, E.A.; Coelho, G.F. Produtividade e componentes de produção da soja adubada com diferentes doses de fósforo, potássio e zinco. Ciência e Agrotecnologia 2010, 34, 660-666. [CrossRef]

106. Smith, M.R.; Golden, C.D.; Myers, S.S. Potential rise in iron deficiency due to future anthropogenic carbon dioxide emissions. GeoHealth 2017, 1, 248-257. [CrossRef]

107. Rengel, Z.; Graham, R.D. Wheat genotypes differ in Zn efficiency when grown in chelate-buffered nutrient solution. I. Growth. Plant Soil 1995, 176, 307-316. [CrossRef]

108. Rengel, Z.; Graham, R.D. Wheat genotypes differ in Zn efficiency when grown in chelate-buffered nutrient solution. II. Nutrient uptake. Plant Soil 1995, 176, 317-324. [CrossRef]

109. Cakmak, I.; Kalaycı, M.; Ekiz, H.; Braun, H.J.; Kılınç, Y.; Yılmaz, A. Zinc deficiency as a practical problem in plant and human nutrition in Turkey: A NATO-science for stability project. Field Crops Res. 1999, 60, 175-188. [CrossRef]

110. Uauy, C.; Distelfeld, A.; Fahima, T.; Blechl, A.; Dubcovsky, J.A. NAC gene regulating senescence improves grain protein, zinc, and iron content in wheat. Science 2006, 314, 1298-1301. [CrossRef]

111. Toklu, F.; Ozkan, H.; Karayoy, T.; Coyne, C.J. Evaluation of advanced lentil lines for diversity in seed mineral concentration, grain yield and yield components. J. Agric. Sci. 2017, 23, 213-222.

112. Waters, B.M.; Sankaran, R.P. Moving micronutrients from the soil to the seeds: Genes and physiological processes from a biofortification perspective. Plant Sci. 2011, 180, 562-574. [CrossRef] [PubMed]

113. Takahashi, M.; Nozoye, T.; Kitajima, N.; Fukuda, N.; Hokura, A.; Terada, Y.; Nakai, I.; Ishimaru, Y.; Kobayashi, T.; Nakanishi, H.; et al. In vivo analysis of metal distribution and expression of metal transporters in rice seed during germination process by microarray and X-ray Fluorescence Imaging of $\mathrm{Fe}, \mathrm{Zn}, \mathrm{Mn}$, and Cu. Plant Soil 2009, 325, 39-51. [CrossRef]

114. Welch, R.M.; Graham, R.D. Breeding for micronutrients in staple food crops from a human nutrition perspective. J. Exp. Bot. 2004, 55, 353-364. [CrossRef] [PubMed]

115. Slamet-Loedin, I.H.; Johnson-Beebout, S.E.; Impa, S.; Tsakirpaloglou, N. Enriching rice with Zn and Fe while minimizing Cd risk. Front. Plant. Sci. 2015, 6, 121. [CrossRef]

116. Ludwig, L.; Slamet, I.H. Genetic biofortification to enrich rice and wheat grain iron: From genes to product. Front. Plant Sci. 2019, 10, 1-10. [CrossRef]

117. Ishimaru, Y.; Kim, S.; Tsukamoto, T.; Oki, H.; Kobayashi, T.; Watanabe, S.; Matsuhashi, S.; Takahashi, M.; Nakanishi, H.; Morit, S.; et al. Mutational reconstructed ferric chelate reductase confers enhanced tolerance in rice to iron deficiency in calcareous soil. Proc. Natl. Acad. Sci. USA 2007, 104, 7373-7378. [CrossRef]

118. Holme, I.B.; Dionisio, G.; Brinch-Pedersen, H.; Wendt, T.; Madsen, C.K.; Vincze, E.; Holm, P.B. Cisgenic barley with improved phytase activity. Plant Biotechnol. J. 2012, 10, 237-247. [CrossRef]

119. Guttieri, M.; Bowen, D.; Dorsch, J.A.; Raboy, V.; Souza, E. Identification and characterization of a low phytic acid wheat. Crop Sci. 2004, 44, 418-424. [CrossRef]

120. Pilu, R.; Panzeri, G.; Gavazzi, G.; Rasmussen, S.; Consonni, G.; Nielsen, E. Phenotypic, genetic and molecular characterization of a maize low phytic acid mutant (lpa241). Theor. Appl. Genet. 2003, 107, 980-987. [CrossRef]

121. Oltmans, S.E.; Fehr, W.R.; Welke, G.A.; Raboy, V.; Peterson, K.L. Agronomic and seeds traits of soybean lines with low-phytate phosphorus. Crop Sci. 2005, 45, 593-598. [CrossRef] 
122. Conte, S.S.; Walker, E.L. Transporters contributing to iron trafficking in plants. Mol. Plant 2011, 4, 464-476. [CrossRef] [PubMed]

123. Regvar, M.; Eichert, D.; Kaulich, B.; Gianoncelli, A.; Pongrac, P.; Vogel-Mikuš, K.; Kreft, I. New insights into globoids of protein storage vacuoles in wheat aleurone using synchrotron soft X-ray microscopy. J. Exp. Bot. 2011, 62, 3929-3939. [CrossRef] [PubMed]

124. Liu, J.; Yang, M.; Li, H.; Li, D.; Shi, X.; Zhang, Y. Genetic processes of iron and zinc accumulation in edible portion of crops and their agro-biofortification: A review. Am. J. Agric. For. 2017, 5, 65-72. [CrossRef]

125. Wu, T.Y.; Gruissem, W.; Bhullar, N.K. Targeting intracellular transport combined with efficient uptake and storage significantly increases grain iron and zinc levels in rice. Plant Biotechnol. J. 2019, 17, 9-20. [CrossRef]

126. Bashir, K.; Takahashi, R.; Akhtar, S.; Ishimaru, Y.; Nakanishi, H.; Nishizawa, N.K. The knockdown of OsVIT2 and MIT affects iron localization in rice seed. Rice 2013, 6, 31. [CrossRef]

127. Subramanyam, K.; Laing, G.D.; Els, J.M.; Van Damme, E.J.M. Sodium selenate treatment using a combination of seed priming and foliar spray alleviates salinity stress in rice Front. Plant. Sci. 2019, 10, 116.

128. Iqbal, M.; Hussain, I.; Liaqat, H.; Ashraf, M.A.; Rasheed, R.; Rehman, A.U. Exogenously applied selenium reduces oxidative stress and induces heat tolerance in spring wheat Plant Physiol. Biochem. 2015, 94, 95-103.

129. Pazurkiewicz-Kocot, K.; Galas, W.; Kita, A. The effect of selenium on the accumulation of some metals in Zea mays L. plants treated with indole-3-acetic acid. Cell. Mol. Biol. Lett. 2003, 8, 97-103.

130. Sohindji, F.S.; Sogbohossou, D.E.O.; Zohoungbogbo, H.P.E.; Houdegbe, C.A.; Achigan-Dako, E.G. Understanding molecular mechanisms of seed dormancy for improved germination in traditional leafy vegetables: An overview. Agronomy 2020, 10, 57. [CrossRef]

131. Vishal, B.; Kumar, P.P. Regulation of seed germination and abiotic stresses by gibberellins and abscisic acid. Front. Plant Sci. 2018, 9, 838. [CrossRef]

132. Daszkowska-Golec, A.; Collin, A.; Marzec, M.; Slota, M.; Kurowska, M.; Gajecka, M.; Gajewska, P.; Płociniczak, T.; Sitko, K.; Pacak, A.; et al. Mutation in HvCBP20 (cap binding protein 20) adapts barley to drought stress at phenotypic and transcriptomic levels. Front. Plant Sci. 2017, 8, 942. [CrossRef] [PubMed]

133. Zhang, H.; Zhu, H.; Pan, Y.; Yu, Y.; Luan, S.; Li, L. A DTX/MATE-type transporter facilitates abscisic acid efflux and modulates ABA sensitivity and drought tolerance in Arabidopsis. Mol. Plant 2014, 7, 1522-1532. [CrossRef] [PubMed]

134. Zeng, D.-E.; Hou, P.; Xiao, F.; Liu, Y. Overexpression of Arabidopsis XERICO gene confers enhanced drought and salt stress tolerance in rice (Oryza sativa L.). J. Plant Biochem. Biotechnol. 2015, 24, 56-64. [CrossRef]

135. Verma, V.; Ravindran, P.; Kumar, P.P. Plant hormone mediated regulation of stress responses. BMC Plant Biol. 2016, 16, 86. [CrossRef]

136. Ravindran, P.; Verma, V.; Stamm, P.; Kumar, P.P. A novel RGL2-DOF6 complex contributes to primary seed dormancy in Arabidopsis thaliana by regulating a GATA transcription factor. Mol. Plant. 2017, 10, 1307-1320. [CrossRef]

137. Yan, A.; Wu, M.; Yan, L.; Hu, R.; Ali, I.; Gan, Y. AtEXP2 is involved in seed germination and abiotic stress response in Arabidopsis. PLoS ONE 2014, 9, e85208. [CrossRef]

138. Huang, H.; Ullah, F.; Zhou, D.X.; Yi, M.; Zhao, Y. Mechanisms of ROS regulation of plant development and stress responses. Front. Plant Sci. 2019, 10, 800. [CrossRef]

139. Parkhey, S.; Naithani, S.C.; Keshavkant, S. ROS production and lipid catabolism in desiccating Shorea robusta seeds during aging. Plant Physiol. Biochem. 2012, 57, 261-267. [CrossRef]

140. Kanwischer, M.; Porfirova, S.; Bergmuller, E.; Dormann, P. Alterations in tocopherol cyclase activity in transgenic and mutant plants of Arabidopsis affect tocopherol content, tocopherol composition, and oxidative stress. Plant Physiol. 2005, 137, 713-723. [CrossRef]

141. Sharma, I.; Pati, P.K.; Bhardwaj, R. Effect of 28-homobrassinolide on antioxidant defence system in Raphanus sativus L. under chromium toxicity. Ecotoxicology 2011, 20, 862-874. [CrossRef]

142. Zhang, J.; Shu, W.S. Mechanisms of heavy metal cadmium tolerance in plants. Physiological and transcriptomic responses in the seed coat of field-grown soybean (Glycine max L. Merr.) to abiotic stress. J. Plant Physiol. Mol. Biol. 2006, 32, 1-8. [PubMed]

143. Leisner, C.P.; Craig, R.; Yendrek, C.R.; Ainsworth, E.A. Physiological and transcriptomic responses in the seed coat of field-grown soybean (Glycine max L. Merr.) to abiotic stress. BMC Plant Biol. 2017, 17, 242. [CrossRef] [PubMed] 
144. Kimotho, R.J.; Baillo, E.H.; Zhan, Z. Transcription factors involved in abiotic stress responses in Maize (Zea mays L.) and their roles in enhanced productivity in the post genomics era. PeerJ 2019, 1-46. [CrossRef] [PubMed]

145. Sujeeth, N.; Mehterov, N.; Gupta, S.; Qureshi, M.K.; Fischer, A.; Proost, S.; Omidbakhshfard, M.A.; Obata, T.; Benina, M.; Staykov, N.; et al. A novel seed plants gene regulates oxidative stress tolerance in Arabidopsis thaliana. Cell. Mol. Life Sci. 2019. [CrossRef] [PubMed]

146. Xi, D.M.; Yang, G.D.; Wu, C.A.; Zheng, C.C. Seed-specific overexpression of antioxidant genes in Arabidopsis enhances oxidative stress tolerance during germination and early seedling growth. Plant. Biotechnol. J. 2010, 8, 796-806. [CrossRef]

147. Liang, Z.; Chen, K.L.; Li, T.D.; Zhang, Y.; Wang, Y.P.; Zhao, Q.; Liu, J.X.; Zhang, H.W.; Liu, C.M.; Ran, Y.D.; et al. Efficient DNA-free genome editing of bread wheat using CRISPR/Cas9 ribonucleoprotein complexes. Nat. Commun. 2017, 8, 14261. [CrossRef]

148. Zhu, J.; Song, N.; Sun, S.; Yang, W.; Zhao, H.; Song, W.; Lai, J. Efficiency and inheritance of targeted mutagenesis in maize using CRISPR-Cas9. J. Genet. Genom. 2016, 43, 25-36. [CrossRef]

149. Li, Z.; Liu, Z.B.; Xing, A.; Moon, B.P.; Koellhoffer, J.P.; Huang, L.; Ward, R.T.; Clifton, E.; Falco, S.C.; Cigan, A.M. Cas9-guide RNA directed genome editing in soybean. Plant Physiol. 2015, 169, 960-970. [CrossRef]

150. Cai, Y.; Chen, L.; Liu, X.; Sun, S.; Wu, C.; Jiang, B.; Han, T.; Hou, W. CRISPR/Cas9-mediated genome editing in soybean hairy roots. PLoS ONE 2015, 10, e0136064. [CrossRef]

151. Shao, G.N.; Xie, L.H.; Jiao, G.A.; Wei, X.J.; Sheng, Z.H.; Tang, S.; Hu, P.S. CRISPR/CAS9-mediated editing of the fragrant gene Badh2 in rice. Chin. J. Rice Sci. 2017, 31, 216-222.

152. Zhang, A.; Feiming, Y.L.; Li, W.T.; Chen, Z.; Kong, D.; Bi, J.; Zhang, F.; Luo, X.; Wang, J.; Tang, J.; et al. Enhanced rice salinity tolerance via CRISPR/Cas9-targeted mutagenesis of the OsRR22 gene. Mol. Breed. 2019, e39, 47. [CrossRef]

153. Bláha, L.; Kadlec, P.; Kohout, L.; Gottwaldová, P.; Čepl, J.; Macháčkova, I.; Hnilička, F. Vigour of seeds, quality of seed and influence of these traits on the selected crops, minor crops and potato for plant breeding, seed production ant plant production. Úroda 2008, 12, 53-60.

(C) 2020 by the authors. Licensee MDPI, Basel, Switzerland. This article is an open access article distributed under the terms and conditions of the Creative Commons Attribution (CC BY) license (http://creativecommons.org/licenses/by/4.0/). 